
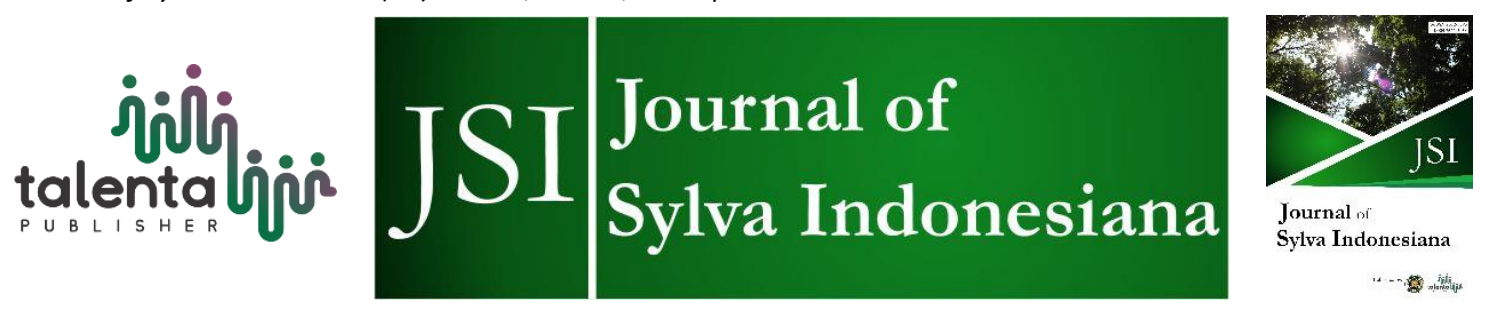

\title{
DNA Barcoding of Rattan (Arecaceae) From Gunung Walat Education Forest, Sukabumi-West Java
}

\author{
Ahmad Baiquni Rangkuti ${ }^{*}$, Arida Susilowati ${ }^{1}$ Ulfa Juniarti Siregar ${ }^{2}$, \\ Laswi Irmayanti ${ }^{3}$, and Iskandar Zulkarnain Siregar ${ }^{2}$ \\ ${ }^{1}$ Department of Silviculture, Faculty of Forestry, Universitas Sumatera, Medan, Indonesia \\ ${ }^{2}$ Department of Silviculture, Faculty of Forestry, IPB University, Bogor, Indonesia \\ ${ }^{3}$ Major of Forestry, Faculty of Agriculture, Khairun University, North Maluku, Indonesia
}

\begin{abstract}
Rattan is a forest plant that has high economic and ecological value. This species grows in various habitats because of its good adaptability. Gunung Walat education forest (GWEF) is an ex-situ conservation location owned by IPB University and rattan conservation potential. In 2005 rattan were planted in this area from some material source in Indonesia, but the information regarding its identity was still limited. Therefore, this study aims to identify rattan in GWEF using barcode methods. Four barcoding those were $r b c L$, matk $\mathrm{K}$, psbA-trn $\mathrm{H}$, and ITS 1 were used for this purpose. Molecular analysis was conducted through DNA extraction using the CTAB method, DNA quality and quantity observation using electrophoresis and Polymerase Chain Reaction (PCR) amplification. The result of this research showed that DNA barcodes show a different pattern of rattan identification. The best candidates for rattan barcode are ITS 1 and $r b c L$.
\end{abstract}

Keyword: DNA Barcoding, Identification, ITS 1, Rattan, $r b c L$

Received 2 February 2021 | Revised 8 February 2021 | Accepted 24 February 2021

\section{Introduction}

Rattan is important plant species for the South Asia community, especially in Indonesia. According to [1] and [2], 516 rattan species can be found in Southeast Asia belonging to 8 genera. The rattan genera were Calamus (333 species), Daemonorops (122 species), Khorthalsia (30 species), Plectocomia (10 species), Calopspata (2 species), Bejaudia (1 species), and Ceratobolus (6 species). Of the eight genera, two of them have high economic value, namely Calamus and Daemonorops [3]. In 2005, at the Gunung Walat Education Forest (GWEF), Sukabumi- West Java, an ex-situ conservation effort was made on rattan to protect its genetic resources. The conservation activities directly increase the amount and species of rattan in that location. The ex-situ conservation activities carried out at GWEF will help protect the genetic

\footnotetext{
*Corresponding author at: Department of Silviculture, Faculty of Forestry, Universitas Sumatera Utara. Jl. Tridharma Ujung No 1, Kampus USU, Medan 20155, North Sumatera Indonesia E-mail address: baiqunirangkuti@usu.ac.id 
source of rattan and become a site for learning about education tours in that location. The problem on this site is the difficulty of identifying the rattan species based on its morphological characters. There are so many rattan species with a relatively similar morphological character in the seedling stage. Therefore, identification of rattan species was needed for further conservation strategy.

DNA barcode is a tool that can identify a living organism by using the nucleotide information in that living organism, so it helps overcome the problem of identification that cannot be covered by morphological identification. DNA barcode is a good approach for discriminating taxon and identification using short genomic regions [4]. Ideally, DNA sequences (barcodes) from the genomic region can be retrieved from small tissues and identify organisms [5]. These sequences are then aligned with the reference sequences database. If it finds a sequence that matches one of the databases leading to identification or record, it is possible to assign a new barcode to a particular species [6]. However, if any references in the database do not meet a match, it can indicate a new species [7].

Research on plant barcode generally uses the $r b c L$ region (ribulase 1,3 biphosphate carboxylase Oxygenase), mat $\mathrm{K}$ (maturase $\mathrm{K}$ ), $p s b \mathrm{~A}-t r n \mathrm{H}$, and ITS (internal transcribed spacer). The ITS is preferable for this purpose because they have a higher rate of evolution, present in all eukaryotic rRNA genes, have multiple copies in the nuclear genome, and short in size [8]. Therefore, further research related to the potential for $r b c L, m a t \mathrm{~K}, \operatorname{trn} \mathrm{H}-p s b \mathrm{~A}$, and ITS1 markers used in rattan as DNA barcode needs to be done to overcome those problems. This study aimed to identify the rattan species that grow $n$ the GWEF using DNA barcode and select the best potential barcode candidates to identify the rattan species.

\section{Materals and Methods}

\subsection{Samples collection}

The Sample collection was conducted by collecting fresh leaf tissue samples of rattan from GWEF. Whereas DNA isolation was conducted at the Forest Genetics and Molecular Forestry Laboratory, Department of Silviculture, Faculty of Forestry, Bogor Agricultural Institute. The map of the leaf sampling location is presented in Figure 1. 


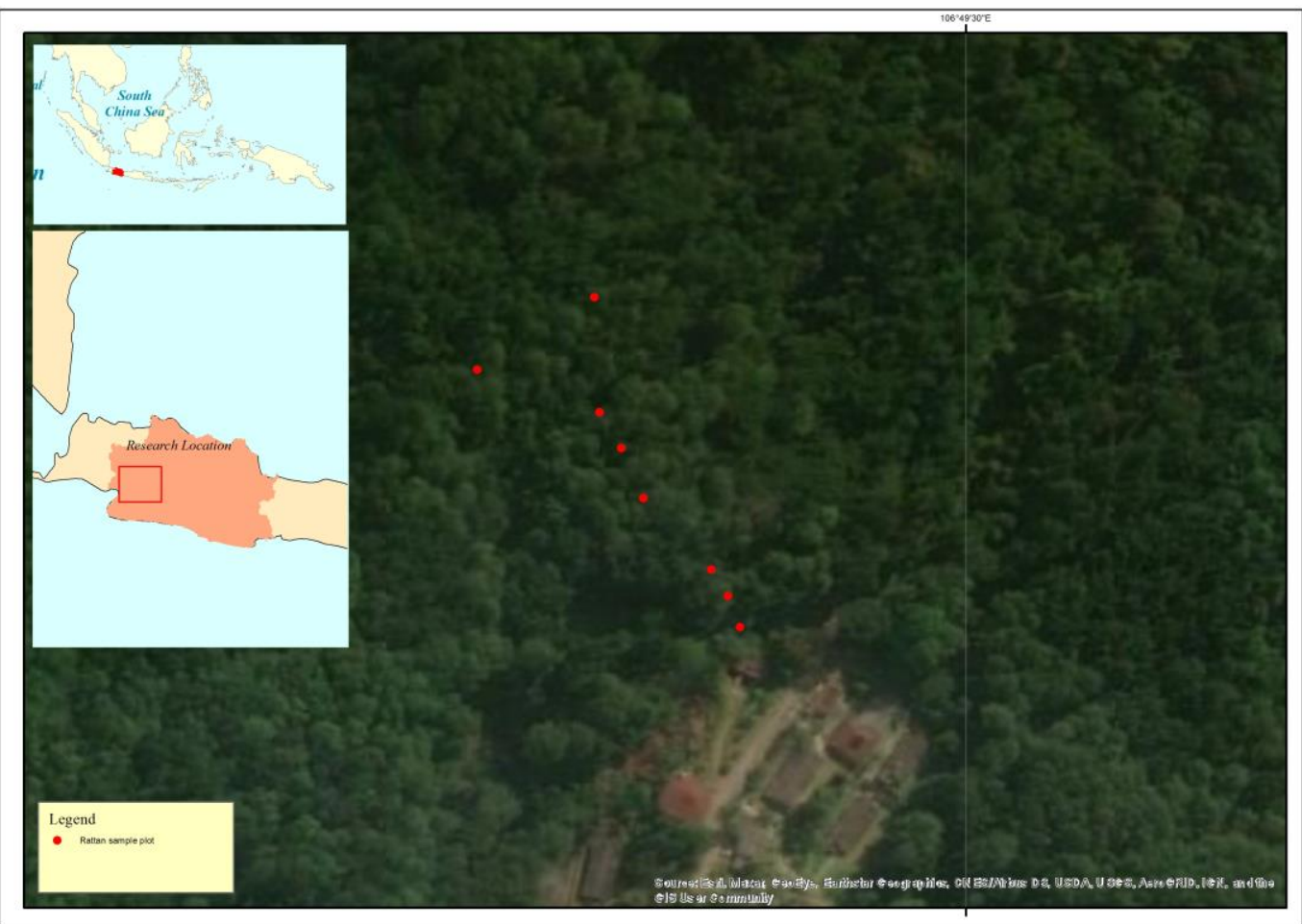

Figure 1 Samples collection location in Gunung Walat Education Forest

\subsection{Research Procedures}

\section{A. Leaves Samples}

Rattan leaves were taken from 9 candidates species found in GWEF based on morphological differentiation. Young leaves with perfect shape are in rows 3-5 on the petiole taken from each rattan. The leaves that have been taken are then cut into $2 \times 2 \mathrm{~cm}$ in the middle position and try not to include the leaf margin so that the grinding process is easier to do. The leaves are then put into an envelope filled with silica gel. The ratio of the number of leaves with silica gel is 1:5. The purpose of storing leaves with silica gel is so that the leaves dry out and avoid fungus. Leaf storage with silica gel was carried out until the extraction process. Replacement of silica gel is important if the silica gel has changed color.

\section{B. DNA Extraction, Amplification, and Sequencing}

The sample's DNA extraction activities were carried out using the CTAB (Cetyl trimethyl Ammonium Bromide) method. The electrophoresis process were performed by adding a $20 \mu \mathrm{l}$ TE buffer to the pellet DNA. Furthermore, centrifugation and take $3 \mu \mathrm{l}$ of DNA and add $2 \mu 1$ of blue juice, for PCR results, the first well is added with $3 \mu 1$ of DNA ladder and electrophoresis for 45 minutes. The electrophoresis results were immersed in $\mathrm{EtBr}$ (Ethidium Bromide) for 15 minutes and then photographed using a UV transilluminator model TFX-20.LM [7]. Universal primers, namely $r b c L, m a t K, p s b \mathrm{~A}-t r n \mathrm{H}$, and ITS 1 were uses in this research (Table 1). The extracted DNA was amplified using the AB Applied Biosystem Veriti TM Thermal Cycler machine. The components used were $\mathrm{H}_{2} \mathrm{O} 2$ ul, Green GoTaq Master Mix 8 ul, Forward and Reverse 2 ul primers, and 2 ul DNA. The PCR DNA sequence was sent to PT. Genetics Science 
Indonesia in Singapore and Macrogen in Korea (http://www.ptgenetika.com) to carry out the sequencing process so that the sequences of each sample that have been worked are obtained.

Table 1 Nucleotide primers for DNA amplification

\begin{tabular}{llcl}
\hline Region & Sequence $\left(5^{\prime}-3^{\prime}\right)$ & Direction & Source \\
\hline \multirow{2}{*}{ ITS1 } & ACGAATTCATGGTCCGGTGAAGTGTTCG & $\mathrm{F}$ & \multirow{2}{*}[9]{} \\
& TAGAATTCCCGGTTCGCTCGCCGTTAC & $\mathrm{R}$ & \\
\multirow{2}{*}{$r b c L$} & ATGTCACCACAAACAGAGACTAAAGC & $\mathrm{F}$ & \\
& GTAAAATCAAGTCCACCRCG & $\mathrm{R}$ & {$[5]$} \\
\multirow{2}{*}{$m a t \mathrm{~K}$} & CGTACAGTACTT TTGTGTTTACGA G & $\mathrm{F}$ & \\
\multirow{2}{*}{$p s$ A } & CCAGTCATCTGGAAATCTTGGTT TTC & $\mathrm{R}$ & {$[5]$} \\
- & GTTATGCATGAACGTAAGCTC & $\mathrm{R}$ & \\
\multirow{2}{*}{$\mathrm{H} \mathrm{H}$} & CGCGCATGGTGGATTCAAATCC & $\mathrm{F}$ & {$[5]$} \\
\hline
\end{tabular}

\section{Data analysis}

The sequence editing process uses Mega 6 Software [10], based on the chromatogram's quality. Sequence data must be free from noise and gaps to continue in the alignment process. Sequence alignment was carried out using Mega 6 software [10]. Then the sequence identification was carried out using BLAST NCBI could be accessed via the following web page: (https://www.ncbi.nlm.nih.gov).

\section{Results and Discussion}

Various studies on the application and use of DNA barcode have been carried out in many purpose such as: in vascular plants in Canada [11], medicinal plants in India [12], the Araliaceae family [13], metabarcoding [14] and durian species [15]. DNA barcode works by comparing short DNA sequences to quickly identify a species [4]. In addition to identifying, DNA barcode has also been able to add taxonomic information based on morphological characters [16].

According to [17], a good barcode must have the following criteria: (1) universality (easy to amplify and sequenced), (2) good quality sequences, and (3) have high difference power from others. This study's barcode candidates consist of four, namely: rbcL, matK, psbA-trnH, and ITS1. Candidates for barcodes have become many good barcodes to identify plants. matK primers, $r b c L$, and $p s b \mathrm{~A}-t r n \mathrm{H}$ were in plant chloroplasts, while ITS 1 was in the nucleus. ITS 1 is used in this study because ITS 1 is a good barcode for taxonomy, especially in fungi. The amplification results of potential $r b c L, p s b \mathrm{~A}-\operatorname{trn} \mathrm{H}, m a t \mathrm{~K}$, and ITS1 barcode candidates on rattan are presented in Figures 1 to 3.

The results showed that $r b c L$ primers and ITS 1 had the highest percentage of both the amplification results and the nine species' sequences whose amplification results reached $100 \%$ in PCR. The annealing temperature used in the PCR process was $58^{\circ} \mathrm{C}$. For both of primers, 
only once did the temperature selection process on PCR annealing. The $p s b \mathrm{~A}-t r n \mathrm{H}$ region of nine samples obtained 7 (seven) samples that were successfully amplified and able to be sequenced well. The success rate using $p s b \mathrm{~A}-\operatorname{trn} \mathrm{H}$ primer reached $77 \%$ and it was successful at $54{ }^{\circ} \mathrm{C}$ annealing temperature.

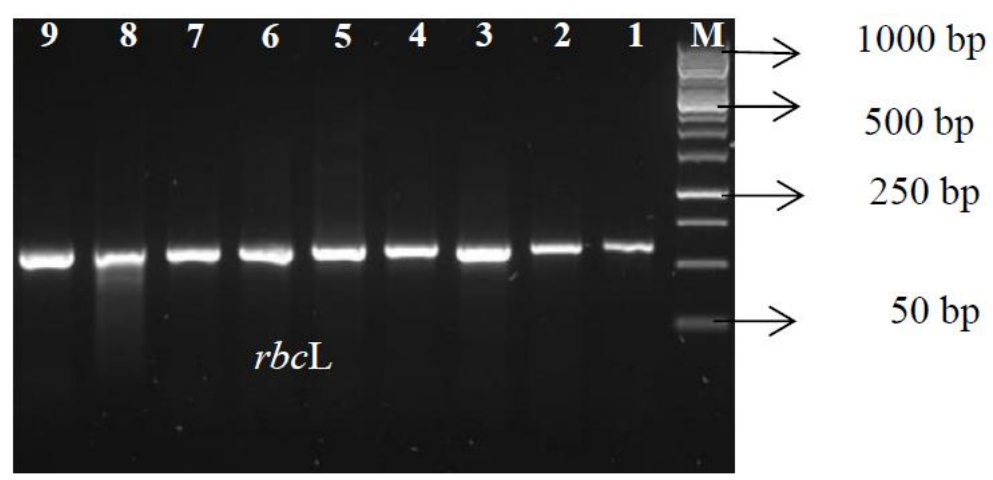

Figure 2 The amplification pattern of rbcL on rattan

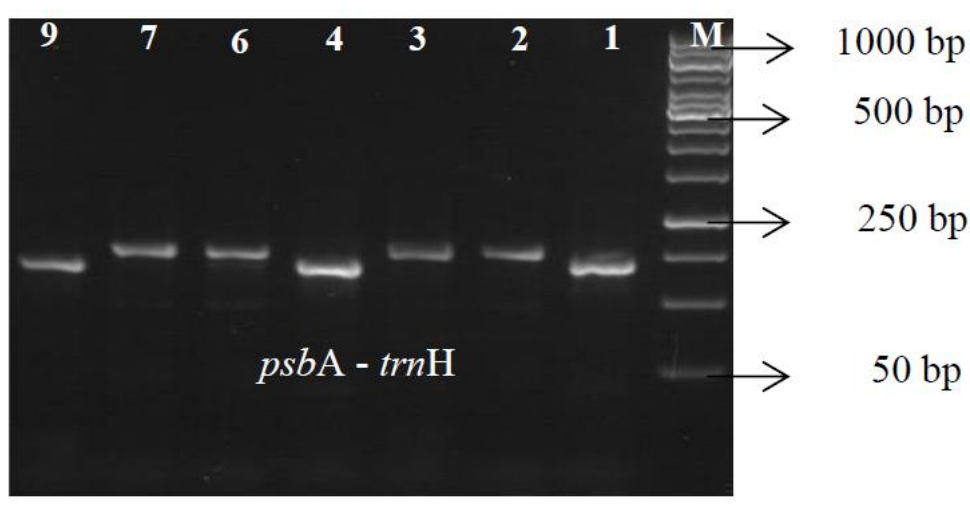

Figure 3 The amplification pattern of psbA-trnH on rattan

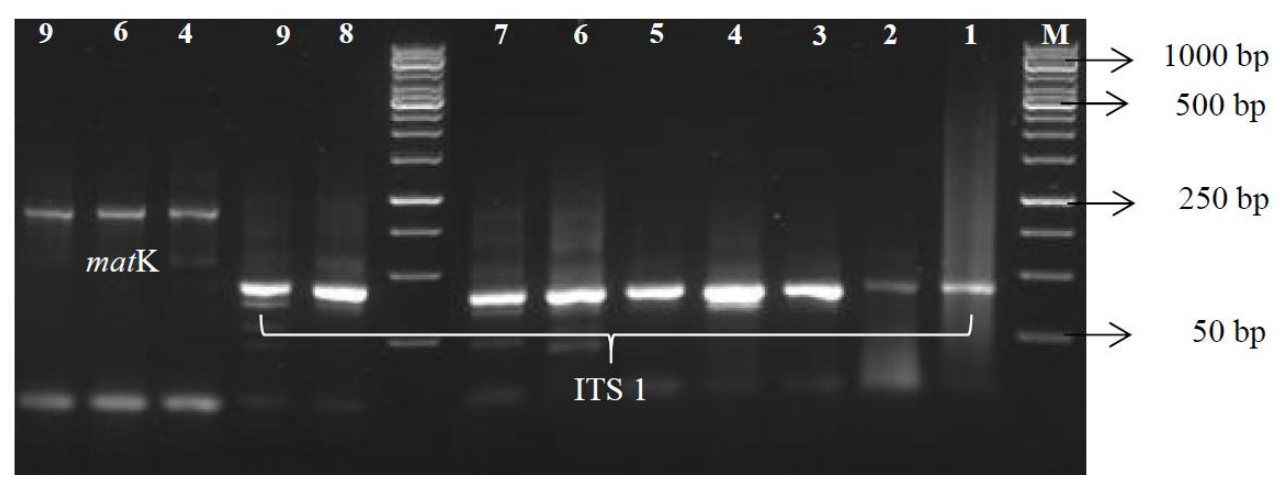

Figure 4 The amplification pattern of matK and ITS1 on rattan

matK primers are primers that have been widely used in various types of plants and have a high success rate. However, in rattan, matK primers had the lowest amplification and sequence yields compared to other primers. Of the nine samples, three (up to 33\%) were successfully amplified in the PCR and sequencing processes. The PCR process was carried out several times by 
changing the annealing temperature. The annealing temperature used was $(56,57,58,59,60,61$

${ }^{\circ} \mathrm{C}$ ) and was successful at $58{ }^{\circ} \mathrm{C}$. According to [18], $r b c L$, trnH-psbA, and matK primers had a high success rate, whereas ITS had low results. This was different from our results, which showed that ITS primer 1 has success rates for amplification (Table 2).

Table 2 Recapitulation of PCR and sequences on rattan

\begin{tabular}{llccc}
\hline $\begin{array}{c}\text { Barcode } \\
\text { Region }\end{array}$ & Primer used & $\begin{array}{c}\text { Number of } \\
\text { Samples }\end{array}$ & $\begin{array}{c}\text { Percentage of } \\
\text { success amplified } \\
(\%)\end{array}$ & $\begin{array}{c}\text { Percentage of } \\
\text { successful } \\
\text { sequences (\%) }\end{array}$ \\
\hline$r b c L$ & $r b c L$ F - rbcL R & 9 & 100 & 100 \\
$m a t \mathrm{~K}$ & $m a t \mathrm{~K}$ 3F - matK 1R & 9 & 33 & 33 \\
$p s b \mathrm{~A}-t r n \mathrm{H}$ & $p s b \mathrm{~A}$ F - trn H R & 9 & 77 & 77 \\
ITS 1 & ITS1 F -ITS1 R & 9 & 100 & 100 \\
\hline
\end{tabular}

After editing the sequence data and it is believed that there are no odd data, the final process to identify the type of plant is to enter the base chain or plant sequence into the Blast column at NCBI (National Center for Biotechnology Information).

NCBI is a place to collect DNA data from various kinds of plants, fungi, and animals in the world. The result of identification presented in Table 4. The BLAST results obtained from the four primers showed the identification of different species with identification rates ranging from 92-100\%. The BLAST results on rbcL primer obtained three rattan species, namely, Calamus moti (R1, R2, R3, R4, R8, R9), C. compsostachys (R5), and C. caryotoides (R6 \& R7). The BLAST results on the matK primer obtained two rattan species, namely: C. salicifolius and C. tetradactylus. $p s b \mathrm{~A}-t r n \mathrm{H}$ primers gave three species of BLAST results, namely: C.caryotoides (R1 and R4), C. travancoricus (R2, R3, R6, and R7) and Oncocalamus mannii (R9). The synonym for Oncocalamus mannii on the Plant List website (http://www.theplantlist.org) is C.mannii. Primers ITS1 gave different results from the other three primers based on BLAST results. There is only one species in all samples (R1-R9 namely Daemonorops didymophylla. The results of the recapitulation of rattan plant identification using DNA barcodes are shown in Table 3. 
Table 3 The identification of rattan species using DNA barcode

\begin{tabular}{|c|c|c|c|c|c|}
\hline No. & Code & Region & BLAST Result & Ident $(\%)$ & $\begin{array}{l}\text { Accession code } \\
\text { (NCBI) }\end{array}$ \\
\hline \multirow{4}{*}{1} & \multirow{4}{*}{ R1 } & $r b c L$ & Calamus moti & 100 & $\begin{array}{c}\text { gi }|530444323| \mathrm{gb} \mid \\
\text { KF496468.1 }\end{array}$ \\
\hline & & matK & - & - & - \\
\hline & & $p s b \mathrm{~A}-t r n \mathrm{H}$ & $\begin{array}{l}\text { Calamus } \\
\text { caryotoides }\end{array}$ & 100 & $\begin{array}{c}\mathrm{gi}|449326336| \mathrm{gb} \mid \\
\text { JX088663.1 }\end{array}$ \\
\hline & & ITS 1 & $\begin{array}{c}\text { Daemonorops } \\
\text { didymophylla }\end{array}$ & 97 & $\begin{array}{c}\text { gi }|7362895| \mathrm{emb} \mid \\
\text { AJ242070.1 } \\
\end{array}$ \\
\hline \multirow{4}{*}{2} & \multirow{4}{*}{ R2 } & $r b c L$ & Calamus moti & 100 & $\begin{array}{c}\text { gi|530444323|gb| } \\
\text { KF496468.1 }\end{array}$ \\
\hline & & $\operatorname{mat} \mathrm{K}$ & - & - & - \\
\hline & & $p s b \mathrm{~A}-t r n \mathrm{H}$ & $\begin{array}{l}\text { Calamus } \\
\text { travancoricus }\end{array}$ & 99 & $\begin{array}{c}\text { gi }|408717677| \mathrm{gb} \mid \\
\text { JX502815.1 }\end{array}$ \\
\hline & & ITS 1 & $\begin{array}{l}\text { Daemonorops } \\
\text { didymophylla }\end{array}$ & 97 & $\begin{array}{c}\text { gi }|7362895| \mathrm{emb} \mid \\
\text { AJ242070.1 }\end{array}$ \\
\hline \multirow{4}{*}{3} & \multirow{4}{*}{ R3 } & $r b c L$ & Calamus moti & 100 & $\begin{array}{c}\text { gi }|530444323| \mathrm{gb} \mid \\
\text { KF496468.1 }\end{array}$ \\
\hline & & $\operatorname{mat} \mathrm{K}$ & - & - & - \\
\hline & & $p s b \mathrm{~A}-t r n \mathrm{H}$ & $\begin{array}{l}\text { Calamus } \\
\text { travancoricus }\end{array}$ & 99 & $\begin{array}{c}\mathrm{gi}|408717677| \mathrm{gb} \mid \\
\text { JX502815.1 }\end{array}$ \\
\hline & & ITS 1 & $\begin{array}{c}\text { Daemonorops } \\
\text { didymophylla }\end{array}$ & 97 & $\begin{array}{c}\text { gi }|7362895| \mathrm{emb} \mid \\
\text { AJ242070.1 }\end{array}$ \\
\hline \multirow{4}{*}{4} & \multirow{4}{*}{ R4 } & $r b c L$ & Calamus moti & 100 & $\begin{array}{c}\text { gi }|530444323| \mathrm{gb} \mid \\
\text { KF496468.1 }\end{array}$ \\
\hline & & mat $\mathrm{K}$ & $\begin{array}{c}\text { Calamus } \\
\text { salicifolius }\end{array}$ & 99 & $\begin{array}{c}\text { gi }|619326159| \mathrm{dbj} \mid \\
\text { AB924994.1 }\end{array}$ \\
\hline & & $p s b \mathrm{~A}-t r n \mathrm{H}$ & $\begin{array}{l}\text { Calamus } \\
\text { caryotoides }\end{array}$ & 100 & $\begin{array}{c}\text { gi }|449326336| \mathrm{gb} \mid \\
\text { JX088663.1 }\end{array}$ \\
\hline & & ITS 1 & $\begin{array}{l}\text { Daemonorops } \\
\text { didymophylla }\end{array}$ & 97 & $\begin{array}{c}\text { gi|7362895|emb| } \\
\text { AJ242070.1 }\end{array}$ \\
\hline \multirow{4}{*}{5} & \multirow{4}{*}{ R5 } & $r b c L$ & $\begin{array}{c}\text { Calamus } \\
\text { compsostachys }\end{array}$ & 100 & $\begin{array}{c}\text { gi }|756776607| \mathrm{gb} \mid \\
\text { KP094748.1 }\end{array}$ \\
\hline & & $\operatorname{mat} \mathrm{K}$ & - & - & - \\
\hline & & $p s b \mathrm{~A}-t r n \mathrm{H}$ & - & - & - \\
\hline & & ITS 1 & $\begin{array}{l}\text { Daemonorops } \\
\text { didymophylla }\end{array}$ & 94 & $\begin{array}{c}\text { gi }|7362895| \mathrm{emb} \mid \\
\text { AJ242070.1 }\end{array}$ \\
\hline \multirow{4}{*}{6} & \multirow{4}{*}{ R6 } & $r b c L$ & $\begin{array}{c}\text { Calamus } \\
\text { caryotoides }\end{array}$ & 100 & $\begin{array}{c}\text { gi|449326336|gb| } \\
\text { JX088663.1 }\end{array}$ \\
\hline & & mat $\mathrm{K}$ & $\begin{array}{l}\text { Calamus } \\
\text { tetradactylus }\end{array}$ & 98 & $\begin{array}{c}\text { gi|619328393|dbj| } \\
\text { AB924767.1 }\end{array}$ \\
\hline & & $p s b \mathrm{~A}-t r n \mathrm{H}$ & & 99 & $\begin{array}{c}\text { gi }|408717677| \mathrm{gb} \mid \\
\text { JX502815.1 }\end{array}$ \\
\hline & & ITS 1 & $\begin{array}{l}\text { Daemonorops } \\
\text { didymophylla }\end{array}$ & 96 & $\begin{array}{c}\text { gi }|7362895| \mathrm{emb} \mid \\
\text { AJ242070.1 }\end{array}$ \\
\hline \multirow{4}{*}{7} & \multirow{4}{*}{ R7 } & $r b c L$ & $\begin{array}{l}\text { Calamus } \\
\text { caryotoides }\end{array}$ & 100 & $\begin{array}{c}\text { gi }|449326336| \mathrm{gb} \mid \\
\text { JX088663.1 }\end{array}$ \\
\hline & & $\operatorname{mat} \mathrm{K}$ & - & - & - \\
\hline & & $p s b \mathrm{~A}-t r n \mathrm{H}$ & $\begin{array}{l}\text { Calamus } \\
\text { travancoricus }\end{array}$ & 100 & $\begin{array}{c}\text { gi }|408717677| \mathrm{gb} \mid \\
\text { JX502815.1 }\end{array}$ \\
\hline & & ITS 1 & $\begin{array}{l}\text { Daemonorops } \\
\text { didymophylla }\end{array}$ & 95 & $\begin{array}{c}\text { gi|7362895|emb| } \\
\text { AJ242070.1 }\end{array}$ \\
\hline \multirow{2}{*}{8} & \multirow{2}{*}{ R8 } & $r b c L$ & Calamus moti & 100 & $\begin{array}{c}\text { gi }|530444323| \mathrm{gb} \mid \\
\text { KF496468.1 }\end{array}$ \\
\hline & & mat $\mathrm{K}$ & - & - & - \\
\hline
\end{tabular}




\begin{tabular}{|c|c|c|c|c|c|}
\hline No. & Code & Region & BLAST Result & Ident $(\%)$ & $\begin{array}{l}\text { Accession code } \\
\text { (NCBI) }\end{array}$ \\
\hline & & $p s b \mathrm{~A}-t r n \mathrm{H}$ & - & - & - \\
\hline & & ITS 1 & $\begin{array}{l}\text { Daemonorops } \\
\text { didymophylla }\end{array}$ & 97 & $\begin{array}{c}\text { gi|7362895|emb| } \\
\text { AJ242070.1 }\end{array}$ \\
\hline \multirow{4}{*}{9} & \multirow{4}{*}{ R9 } & $r b c L$ & Calamus moti & 100 & $\begin{array}{c}\text { gi }|530444323| \mathrm{gb} \mid \\
\text { KF496468.1 }\end{array}$ \\
\hline & & mat $\mathrm{K}$ & $\begin{array}{l}\text { Calamus } \\
\text { salicifolius }\end{array}$ & 99 & $\begin{array}{c}\text { gi }|619326159| \mathrm{dbj} \mid \\
\quad \text { AB924994.1 }\end{array}$ \\
\hline & & $p s b \mathrm{~A}-t r n \mathrm{H}$ & $\begin{array}{c}\text { Oncocalamus } \\
\text { mannii }\end{array}$ & - & 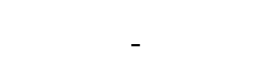 \\
\hline & & ITS 1 & $\begin{array}{l}\text { Daemonorops } \\
\text { didymophylla }\end{array}$ & 92 & $\begin{array}{c}\text { gi }|7362895| \mathrm{emb} \mid \\
\text { AJ242070.1 }\end{array}$ \\
\hline
\end{tabular}

\section{Conclusion}

The identification with the four primers shows different results. The $r b c L$ primer found three rattan species, namely Calamus moti, Calamus compsostachys, and Calamus caryotoides. In the matK primer, two species were obtained, namely Calamus salicifolius and Calamus tetradactylus. In the $p s b \mathrm{~A}-t r n \mathrm{H}$ primer, three species were found: Calamus caryotoides, Calamus travancoricus, Oncocalamus manii, and the ITS 1 primer only one species was found, namely Daeromonorops didmophylla. The rbcL primers and ITS 1 have amplification results and $100 \%$ sequences so that these two primers are recommended to be DNA barcode on rattan.

\section{REFERENCES}

[1] Dransfield, J., A. Short Guide to Rattans. BIOTROP. Bogor, 1974.

[2] Menon, K.K. Rattan. A Statet of the Art Review. A paper for presentation the workshop on the cultivarion and processing of rattan in Asia to be held in Singapore, June 1979.

[3] Herliyana, E.N. "Identifikasi Jamur Mold dan Blue Stain Pada Rotan," Jurnal Ilmu dan Teknologi Hasil Hutan, vol. 2, no. 1, pp. 21-26. 2009.

[4] Hebert, P.D.N., Cywinska, A., Ball S.L, and de Waard, J.R. "Biological identifications through DNA barcodes," Proceedings of the Royal Society B 270, pp. 313-321. 2003.

[5] Kress, W.J., and Erickson, D.L. "A two-locus global DNA barcode for land plants: the coding $r b c L$ gene complements the non coding $t r n \mathrm{H}-p s b \mathrm{~A}$ spacer region," PLoS ONE, vol. 2, p. e508. 2007.

[6] Hajibabaei, M., Singer, G.A.C., Hebert, P.D.N., and Hickey, D.A. "DNA Barcoding: How It Complements Taxonomy, Molecular Phylogenetics And Population Genetics," Science direct, vol. 4, pp. 167-172. 2007.

[7] Hebert, P.D.N., Stoeckle, M.Y., Zemlak, T.S., and Francis, C.M. "Identification of birds through DNA barcodes," PLoS Biology, vol. 2, no. 10, p. e312. 2004. doi:10.1371/journal. pbio.0020312.

[8] Kress, W.J., Erickson, D.L., and Jones, F.A. "Plant DNA barcodes and a community phylogeny of a tropical forest dynamics plot in Panama," in Proceedings of the National Academy of Sciences of the United States of America, 106, pp. 1862118626. 2009.

[9] Sun, Y., Skinner, D.Z., Liang, G.H., and Hulbert, S.H. "Phylogenetic analysis of sorghumand related taxa using Internal Transcribed Spacers of nuclear ribosomal DNA," Theor Appl Gen vol. 89, pp. 26-32. 1994. 
[10] Tamura K, Dudley J, Nei M, Kumar S. "MEGA 4: Molecular evolutionary Genetics analysis (MEGA) Software version 4.0," Mol Biol Evol vol. 24, pp. 1596-1599. 2011.

[11] Kuzmina, M. L., Braukmann, T. W. A., Fazekas, A. J., Graham, S. W., Dewaard, S. L., Rodrigues, A., et al. "Using herbarium-derived DNAs to assemble a large-scale DNA barcode library for the vascular plants of Canada," Appl. Plant Sci. vol. 5, no. 11. 2017.

[12] Kumar, J. U. S., Krishna, V., Seethapathy, G. S., Ganesan, R., Ravikanth, G., and Shaanker, R. U. "Assessment of adulteration in raw herbal trade of important medicinal plants of India using DNA barcoding," 3 Biotech vol. 8, no. 135. 2018.

[13] Liu Z, Zeng X, Yang D et al. "Applying DNA barcodes for identification of plant species in the family Araliaceae," Gene no. 499, pp. 76- 80. 2012.

[14] Leontidou, K., Vernesi, C., De Groeve, J., Cristofolini, F., Vokou, D., and Cristofori, A. "DNA metabarcoding of airborne pollen: new protocols for improved taxonomic identification of environmental samples," Aerobiologia no. 34, pp. 6374. 2018.

[15] Sunaryo W, Hendra M, Rudarmono et al. "Exploration and identification of Lai Durian, new highly potential cultivar derived from natural crossing between Durio zibethinus and Durio kutejensis in East Kalimantan," Asian J Microbiol Biotech Env Sci vol. 17, no. 2, pp. 1-7, 2015.

[16] Hebert PDN \& Gregory TR. "The promise of DNA barcoding for taxonomy," System Biology no. 54, pp. 852-859. 2005.

[17] Hollingsworth, P. M., Graham, S. W. \& Little, D. P. "Choosing and using a plant DNA barcode," PLoS ONE vol. 6, no. 5, p. e19254. 2011.

[18] Yang, H. Q., Dong, Y. R., Gu, Z. J., Liang, N. \& Yang, J. B. "A preliminary assessment of matK, $r b c L$ and $t r n \mathrm{H}-p s b \mathrm{~A}$ as DNA barcodes for Calamus (Arecaceae) species in China with a note on ITS," Ann. Bot. Fennici vol. 49, pp. 319-330. 2012. 